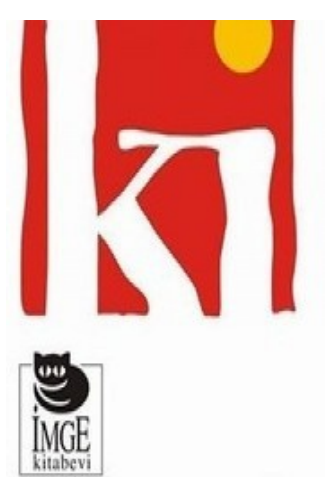

\author{
Kültür ve İletişim \\ culture\&communication
}

Yıl: 22 Sayı: 44 (Year: 22 Issue: 44)

Eylül 2019-Şubat 2020 (September 2019-February 2020)

E-ISSN: 2149-9098

\title{
Eril Diplomasi Kültürüne Feminist Bir Eleştiri"
}

\author{
Zehra Yilmaz
}

Öz

Makalede, diplomasi kültüründe egemen olan eril yapının kadın ve diplomasi arasında ne tür gerilimler yarattığı ve bu gerilimlerin hangi tarihsel ve teorik tartışmalar bağlamında dönüşüm yaşadığı tartışılmaktadır. Dış politika başından beri özellikle de realist akımın etkisiyle kadın hareketinin çok geç nüfuz ettiği bir alan olmuştur. Kadın hareketinin tarihi 19. yüzyılın sonuna dayanmasına rağmen, bu hareketin dış politika tartışmalarına etkisini ancak 1980'ler itibariyle görebilmekteyiz. Uluslararası İlişkiler disiplininde devlet ve güvenlik odaklı realist düşünceye dayalı perspektife getirilen ve alanda "Üçüncü tartışma" olarak adlandırılan eleştiri; dış politikaya insani meseleleri, cinsiyet ve çevre gibi konuları da dahil etmek üzere yeni bir bakış açısı getirmiştir. Bu bağlamda dış politikada karar alma sürecinde kadınlara yer verilmemesine; savaş, güvenlik gibi konuların erkek odakı bakış açıları çerçevesinde çözümlenmesine karşı çıkan eleştirilerle kadın haklarına ilişkin tartışmalar geç de olsa disipline dahil olmayı başarmıştır. Bu tartışmaların etkisiyle dış politikada karar alma süreçlerinde yer alan kadın sayısı da artmıştır. Tarihsel ve teorik tartışmalar çerçevesinde makalede öncelikle dış politikanın epistemolojisine ilişkin kadın hareketinin eleştirileri ele alınmaktadır. Daha sonra kadın hareketinin dış politika konularına eklediği yeni bakış açıları ve bu bakış açılarının eril diplomasi kültürünün değişimine nasıl etkisi olduğu tartışılmaktadır. Son olarak tüm bu tartışmaların hem dünyadaki hem de Türkiye'deki diplomatik temsilciliklere yansıması değerlendirilmektedir. Feminist tartışmaların ve kadın temsilinin dış politika kültürünün değişimine ne tür etkileri olduğunu değerlendirmek bakımından makalenin mevcut tartışmalara yeni bir katkı sağlaması hedeflenmektedir.

Anahtar Sözcükler: Egemen erkeklik, diplomasi, dış politika, kadın temsili, feminizm

\footnotetext{
${ }^{*}$ Geliş tarihi: 12/07/2019 • Kabul tarihi: 04/09/2019

** Van Yüzüncü Yıl Üniversitesi İktisadi ve İdari Bilimler Fakültesi, Uluslararası İlişkiler Bölümü Orcid no: 0000-0002-6980-6470, zehrayilmaz@yyu.edu.tr
} 


\title{
A Feminist Critic of Masculine Diplomacy Culture*
}

\author{
Zehra Yılmaz $^{* \star}$
}

\begin{abstract}
This article discusses the kind of tensions that are created between women and diplomacy by the masculine structure that dominates the diplomacy culture, and how these tensions have been transforming around which historical and theoretical arguments. In fact, especially with the influence of realist movement, foreign policy has been a field where women's movement has penetrated quite late. While history of women's movement goes back to late $19^{\text {th }}$ century, we can only see the influence of this movement on foreign policy discussions as late as 1980s. So called "Third big argument" criticising the state and the security oriented perspectives those based on realist movement in International Relations, has introduced a new perspective into foreign policy, which has been suggesting to include other matters such as humanitarian issues, gender, and environment. In this context, criticisms on excluding women in foreign policy decision making process and solving matters such as war and security with a strictly male perspective, has managed to introduce women's right discussions into this discipline. With the help of these discussions, the number of women partaking in decision making process in foreign policy has increased. Within the framework of historical and theoretical discussions, this article addresses the criticisms of women's movement regarding epistemology of foreign policy. Later on, the article discusses the new perspectives added to foreign policy matters by women's movement, and how these perspectives affected the changes within masculine diplomacy culture. Finally, the reflections of these discussions on diplomatic missions both in Turkey and all over the world are assessed to conclude the article. The article aims to make new contributions to the current discussions in terms of evaluating how feminist discussions and women's representation has affected the change in foreign policy culture.
\end{abstract}

Keywords: Hegemonic masculinity, diplomacy, foreign policy, woman representation, feminism

\footnotetext{
${ }^{*}$ Received: 12/07/2019 • Accepted: 04/09/2019

** Van Yüzüncü Yıl University Faculty of Economics and Administrative, Department of International Relations Orcid id: 0000-0002-6980-6470, zehrayilmaz@yyu.edu.tr
} 


\section{Eril Diplomasi Kültürüne Feminist Bir Eleştiri}

Uluslararası sistemde diplomasinin önem kazanmasında bir eşik olarak kabul edilen 1815 Viyana Kongresi sırasında o dönem “Courland Dükü’nün kızı” olarak bilinen Prusyalı Wilhelmine de Sagan'ın, Metternich'le diyaloğu ve diyaloğun kongredeki etkisi dolayısıyla Avusturya temsilcisinin kendisine şöyle dediği söylenir: "Eğer bir erkek olsaydın... sen büyükelçi ben de bakan olurdum!" (Demel, 2016). Ardından kongre sırasında büyükelçi eşlerinin kongrede, kocalarının "gölgesi" olarak önemli etkiler yarattıklarından methiyelerle söz edilir. Kadınların diplomatik ilişkilerdeki etkisinin bir erkeğin "karısı", "kızı” ya da "annesi” olmanın ötesine geçmesi, "gölge" değil "özne" olmaya başlamaları için yirminci yüzyılın ortalarına kadar beklemeleri gerekir. Bu bekleyişin ardındaki neden, giriş cümlesinde yer verdiğim anekdotta da açık edildiği üzere diplomasinin bir erkek mesleği olarak algılanmasıdır. Bu çerçevede elinizdeki çalışma öncelikle dünyanın çeşitli yerlerinde farklı kurumlarda kadınlara uygulanan ayrımcılığın kökeninde yatan egemen/hegemonik erilliğin dış politika kültürüne nasıl yansıdığını araştırmaya odaklanmıştır. Bu anlamda dış politikaya hâkim olan eril kültürün dış politikada kadın temsilini nasıl ikincilleştirdiği üzerine yapılan önceki çalışmalara bir katkı niteliğindedir.

Son yıllarda uluslararası ilişkiler disiplininin eril, batı yanlısı ve devlet merkezli yapısına ilişkin bir literatür birikmiştir (Enloe, 1990: 11; Hooper, 2001: 41; Zalewski ve Parpart, 1998: 5; Tickner,1999: 44-46; Blanchard, 2003: 1293). Hatta bu literatür, "dış politika" kavramı ve analizine yönelik eleştirileriyle disiplinin varlığı açısından bir tehdit olarak bile tanımlanmaktadır. Bu anlamda kendisini içeriden en fazla eleştiren disiplinlerden biri de uluslararası ilişkilerdir. Sözünü ettiğim çalışmalarda, kadınların diplomasideki temsili ve bunun yapısal olarak eril sistemle ilişkisi, savaş ve kadın arasındaki ilişki, karar alma süreçlerinden kadınların dışlanmasının politika yapma sürecine etkileri gibi konular ele alınmıştır. Elinizdeki çalışma ise bir kültür olarak erilliğin dış politikayla ilişkili diplomatik kurumların gelişiminde ve temsilcilerin seçiminde nasıl belirleyici olduğunu irdelemektedir. Bu nedenle de öncelikle diplomasi kültürünün içerdiği egemen erilliği açığa çıkarmayı hedeflemektedir. Bu bağlamda, eril hegemonyanın görünmez bir el gibi kurumsal kültürü nasıl belirlediği, bu süreçte diplomaside kadınların da eril değerleri ele geçirmek yoluyla bu iktidarda 
kendilerine nasıl yer edindikleri ve sözü edilen eril kültürü normalleştirmeye katkıları makalenin temel sorunsalını oluşturmaktadır. Ancak eril kültüre geçmeden önce, kültürün ne olduğuna ilişkin bir tanımlama yapmak gerekir.

Kültür yaygın kullandığımız kavramlardan biri olmasına rağmen, üzerine çokça tanımlamanın da yapıldığı karmaşık bir kavramdır. Terry Eagleton’a göre, kültür bazı temel felsefi meselelerin şifresidir. Buna göre, kültür özgürlük ve determinizme, eylemlilik ve dayanıklılığa verilen ve yaratılana ilişkin pek çok soruyu muğlak bir biçimde içinde barındıran bir kavramdır (Eagleton, 2011: 11). Bu makale bağlamında, kültürün tanımına ilişkin en kritik vurgu "verili olan ve yaratılan" arasındaki ilişkidedir. Uluslararası ilişkiler disiplininin kuruluşunda insan doğasının - ki bu insan erkektir ${ }^{1}$ “iyi mi? kötü mü?” olduğu üzerine yapılan kurucu tartışmanın "doğacı” varsayımları ve bu tartışmanın kötü olanın galibiyetiyle sonuçlanması, dış politika yaratımında en belirleyici unsur olmuştur diyebiliriz. Zira kültürün en temel sorunsallarından biri olan neyin doğal neyin inşa edildiğine ilişkin paradoks realizmde, insan doğasının kötü olduğu referansıyla çözülmüştür. Realistler insan doğasının kötü olduğu varsayımına dayanarak; uluslararası sistemi anarşik bir düzlemde inşa eder. Bu sistemde devletlerin varlıklarını (bekasını) sadece aktif, güçlü, çıkar odaklı ve savaşçı bir dış politikayla sürdürebilecekleri öne sürülür. Soğuk Savaş döneminde $A B D$ hegemonyasına ${ }^{2}$ eklemlenen realizm, tümünü eril değerler üzerinden tanımladığı kavramlarla (güç, iktidar, güvenlik, çıkar, anarşi) dünyayı açıklar ve aynı zamanda yapılandırır. Uluslararası ilişkiler disiplinindeki kurucu teorisyenlerin tümünün erkek

\footnotetext{
${ }^{1}$ J. Ann Tickner, dış politika analizini merkezine alan uluslararası ilişskiler disiplininin başından itibaren erkek merkezli olduğunu öne sürer. Tickner, disiplinin egemen teorisi olan realizmin kurucu isimlerinden Hans Morgenthau'nun insan doğasına ilişkin görüşlerinin erkeksi ön kabullerle kavramsallaştırıldığından başlayarak eleştirisini öncelikle realizmin önkabullerine yöneltir (1991: 27-32). Ayrıca Tickner'a göre Morgenthau ve Thomas Hobbes'un görüşlerinde kullandığı "insan insanın kurdudur", "insan doğası gereği kötüdür" varsayımları da aslında erkek doğası temel alınarak oluşturulmuştur. Hobbes'un Leviathan'ından başlayarak realizmin referans isimlerinden Niccolo Machiavelli ve yapısalcı realistlerden Kenneth Waltz'un çalışmalarında devleti yöneten hep erkektir. Zira Waltz'un kitabının isminin Man, State and War olması ve Machiavelli'nin kitabının isminin Prince olması bu bakış açısını teyit eder. Tickner dış politikada sıkça rastlanan "prens" ve "prenses" nitelendirmelerinin temelinin Machiavelli'nin "Prince" adll eserine dayandığını söyler ve bunu eleştirir (1999: 44-48).

${ }^{2}$ Soğuk Savaş döneminde, realist teori çerçevesinde kurulan bu yeni yapının ABD için oldukça işlevsel olduğunun altını çizelim. Zira realist düşünürlerin çoğunun $\mathrm{ABD}$ kökenli olması-Michel Foucault’yu anımsayarak söylersek- bilgi ve iktidar ilişkisine ilişkin eşsiz bir örnek olarak adeta disipline ve sisteme damga vurmuștur. Bu bağlamda Soğuk Savaş döneminde hem başkan danışmanlığı hem de dış işleri bakanlığı yapan; ABD dış politikasının mimarı olarak anılan Henry Kissenger'in da aynı zamanda realist teorinin en önemli isimlerinden biri olması anlamlıdır. Kissenger'ın hacimli eseri Diplomasi dış politikanın kurallarının tanımlanması açısından klasik eserlerden biri sayılır.
} 
olması ${ }^{3}$ ve egemen teori olan realizmin tüm argümanlarının eril bir dille oluşturulmuş olması dış politikanın eril kültürünü gösteren örneklerdendir.

Kültür üzerine düşünen Eagleton, aynı zamanda kültürün kazanılan bir olgu olduğunu ve diğer kuşaklara da aktarılabildiğini terimin tanımına ekler. Bir başka ifadeyle, inşa edilebilen kültür, aktarımlar yoluyla yapısal ve değişmez bir özellik de kazanabilmektedir. Böylece bir tür egemenlik aracına da dönüşebilmektedir. Hatta Eagleton bu noktada kültür ve din arasındaki geçişkenliğe de dikkat kesilir ve şöyle der: "Kültürel hakikatler -insanların ister yüksek deneyimleri ister gelenekleri olsunbazen kutsal hakikatlerdir; korunur ve saygı görürler" (2011: 10). Kültürün eril sistemle ilişkisi de burada, erkek egemen kültürün değişmez bir hakikat olarak algılanmasındadır. Kurumsal düzlemde kültürü inşa etme ve aktarma eylemi belli bir cinsiyet aracılığıyla gerçekleşiyorsa biz burada cinsiyetçi bir kültürden söz edebiliriz. Hakikat erkekler aracılığıyla üretiliyorsa, hakikatin de eleştirel bir bakışla yeniden ele alınması elzemdir. Zira hakikati belirleyen eril kültür, bizim için inşa edilmiş "doğal" olanı, daima eril eril değerle ilişkilendirir.

Uluslararası Ilişkiler disiplinin önemli teorisyenlerinden Fred Halliday de benzer bir konuya değinir. Halliday'e göre (1991); kurucu bir teori olarak realizmde güç, çıkar, güvenlik kavramlarının vurgulanması ve bu kavramların alıcı bulması disiplinde bir tür "tembellik" yaratmıştır. Çünkü realizm gerçeklik/doğal olan neyse devletlerin de ona uygun hareket etmesi gerektiğini söyler. Gerçekliği güç ve güvenlik ikileminde tanımlamak Soğuk Savaş dönemi hegemonik mücadelede oldukça işlevsel bulunur. Ancak Halliday'ın sözünü ettiği bu tembelliği bozan 1980'lerde Soğuk Savaş'ın sona ermesiyle başlayan "Üçüncü Tartışma"dır. ${ }^{4}$ Disiplin içindeki bu tartışmayla birlikte yüksek politika (high politics) ve alçak politika (low politics) arasındaki ayrım ortadan kalkmış ve başta realizm olmak üzere geleneksel yaklaşımlar sorgulanmaya başlanmıştır. Bu sorgulamalardan biri de feministler tarafından "Kadın nerede?" sorusuyla başlatılmıştır.

Üçüncü tartışmayla birlikte, yani 1980 'ler sonrasında "alçak politikanın" da uluslararası ilişkiler disiplininde tartışmalara dahil edilmesiyle birlikte çevre sorunları,

\footnotetext{
${ }^{3}$ Edward Hallett Carr, Hans Morgenthau, Niccolo Machiavelli, Kenneth Waltz.

${ }^{4}$ Uluslararası İlişkiler disiplininde kuramsal ve yöntemsel olarak üç belirleyici tartışmanın yapıldığı bilinir. Bunlardan ilki 1930'larda yapılan İdealizm-Realizm arasındaki tartışmadır ki; aynı zamanda "kurucu tartışma" olarak bilinir. İkincisi 1960'larda yapılan Gelenekselciler ve Davranışsalcılar arasındaki yöntemsel tartışmadır. Üçüncü tartışma ise 1980 'lerde disiplinin pozitivist temellerine yönelik eleştiriler üzerinden şekillenen Pozitivist ve Post-Pozitivistler arasındaki tartışmadır.
} 
göç, bilgi-iktidar ilişkisi gibi konular ele alınmaya başlanmış, disiplin devlet odaklı dış politika analizlerinin ötesine geçerek ulus-ötesi bir nitelik kazanmaya başlamıştır. Feminist tartışmaların disipline dahil olabilmesi de bu dönemde, ancak uluslararası ilişkiler disiplini analizlerinin ulus-ötesi özellikler kazanmasıyla mümkün olabilmiştir. Sosyal bilimler içinde en geç feminist tartışmalarla buluşan disiplin uluslararası ilişkilerdir. Bunun en temel nedeni disiplinin güçler dengesine dayalı eril yapısıdır (Çevik ve Bilgiç, 2018: 178). Dolayısıyla diplomasinin eril kültürü ve bu kültür içinde kadınların temsili meselesine bakarken, disiplinin teorik tartışmalarına da eş zamanlı bakmak kaçınılmazdır. Zira diplomasi kurumunun içinde kadınların görünmezliği, silikleştirilmesi uluslararası ilişkiler disiplininin gelişiminin ve teorisinin eril yapısıyla yakından ilişkilidir. Nitekim tüm bu eleştirilere rağmen uluslararası ilişkiler literatüründe halen en çok kullanılan teori realizmdir (Aydın, Hisarlıoğlu ve Yazgan, 2014: 15).

Bu tarihsel ve teorik tartışmalar çerçevesinde makalede öncelikle dış politikanın epistemolojisine ilişkin feminist teorinin eleştirileri ele alınacaktır. Feminist eleştiriler yoluyla birinci bölümde dış politikadaki eril kültür açığa çıkarılacak; daha sonra da ikinci bölümde feminist teorinin dış politika konularına eklediği yeni bakış açıları ve bu bakış açılarının eril diplomasi kültürünün niceliksel olarak değişimine nasıl etkisi olduğu tartışılacaktır. Son bölümde ise tüm bu tartışmaların niteliksel olarak diplomasi kültürünü nasıl değiştirdiği ya da değiştiremediği değerlendirilecektir. Kadın diplomatlarla yapılan görüşmeler, deneyimlerini aktardıkları kitaplar ve kadın temsilindeki değişimi takip edebileceğimiz sayısal veriler teorik tartışmaları sınayacağımız kaynaklar olarak kullanıımışır.

\section{Cinsiyetli Dış Politika Kültürü}

Diplomasi "katı" kuralların egemen olduğu bürokratik kurumlardan biridir. Bu "katı" kurallar vurgusu devletle ilişkili kurumlar arasında çoğunlukla askeri kurumlar için kullanıır. Oysa eski kullanımıyla "hariciye" ve "askeriye" aynı bağlam içinde şekillenen biri militer, diğeri sivil ancak birbirini tamamlayan iki yapı gibidir. Biri devletin egemenlik sınırlarının güvenliğini, diğeri ise devletin egemenlik sınırlarının uluslararası alandaki tanınırlığını sağlar. Söz konusu olan güvenlik, egemenlik ve devletin temsil edilmesi olunca her ikisi de eril düzlemde kesişir. Bu nedenle, her iki 
kurum da yapısal olarak kadınların müdahilliğine direnç gösterir. Craig Murphy, uluslararası ilişkiler alanının eril yapısı üzerine yaptığı çalışmasında, erilliğin değişik tiplerini ele alır ve bunlar içinde uluslararası ilişkilerle en fazla bağlantısı olanları şöyle sıralar: "iyi bir asker", "stratejist", "asker çocuğu", "silah arkadaşı", "popüler barış yanlısı" ve "bitmek tükenmek bilmeyen barış çalışanı" olmak (1998: 93-108). Murphy’nin de gösterdiği üzere, uluslararası ilişkilerle egemen erilliğin kesiştiği çokça alan mevcuttur.

Bir devletin diğer devletlere ve uluslararası kuruluşlara karşı davranışlarının bütününü içeren dış politika ve bunun hayata geçirildiği alan olarak diplomasi, eril kültürün egemen olduğu bir alandır. Zira cinsiyete ilişkin egemen ataerkil kalıplar ve bu ataerkil kalıpların ürettiği "kadınların bağımlıı̆ını doğuran bir dizi kurumsal ve kültürel uygulamalar" (Kandiyoti, 2011: 328) diplomasi kültüründe oldukça belirleyicidir. Diplomasiye kadınların katıımının oldukça geç olması, ardından kadınların üst düzey görevlere gelmesinin ertelenmesi, "diplomat eşi” misyonunun kadınları dikkate alarak dizayn edilmesi bu kültürün yansımalarıdır. Eril kabullerle kurulu olan bu kültür, var olan sistemi kurumsallaştırarak kendisini de bu kabuller üzerinden yenilemekte ve bir kısır döngü oluşturmaktadır.

Kültürel bir aktarım olarak egemen erkeklik, kurumları yapısal olarak belirlemektedir. Egemen erkeklik kurumlarda "sürekli başka konumların 'ne olduğu' hakkında konuşma hakkını kendi elinde tutan ve bu sayede kendi bulunduğu konumu sorgulama dışı kılan bir 'iktidar' konumu" (Sancar, 2009: 16) olarak çalışır. Böylece devleti, dış politikada temsil edecek kişinin erkek ve ona "eş", "yardımcı" ya da "destekçi” tanımlananın da kadın olması doğallaşmakta, diplomasi kültürünün bir parçası haline gelmektedir.

Bu "doğallaştırılan" kültürün biyolojik olarak erkek ya da kadın olmanın ötesinde inşa edilen erkeklik ve kadınlıkla ilişkili olduğunu savunan R. W. Connell, toplumsal hiyerarşilerin yeniden belirlenmesinde cinsiyetin de belirleyici olduğunu söyler (1995: 68). Benzer bir düşünceyi savunan Charlotte Hooper'a göre ise (2001: 54-55), egemen eril yapı tüm toplumun tek bir düzeyini, erkek gücünü ve erkek olmanın avantajlarını ifade eden baskın erkeklik modellerinin bir bütünüdür. Zira, egemen erkeklik, öncelikle erkeklik temelinde ortaya çıkan bir kavram olarak düşünülse de, bunun ötesinde her zaman sosyal yapıyla ilişkili olmuştur (Leatherman, 2005: 103- 
104). Cinsiyet ve toplumsal cinsiyet kavramları arasındaki farklılık da buradan kaynaklanır. Cinsiyet kavramı herhangi bir kişinin genetik, fizyolojik ya da biyolojik özelliklerini işaretlemek üzere kullanılırken; "toplumsal cinsiyet" kavramı toplumun bireyi nasıl gördüğü, algıladığı ve buna bağlı bir biçimde kültürel olarak nasıl şekillendirdiğiyle ilgili bir kavramdır. "Cinsiyeti" doğa, "toplumsal cinsiyeti" ise kültür belirler (Johnston vd., 2001). Bu bağlamda erkeklik ve erkek olmak arasında olduğu gibi kadın olmak ve kadınlık arasında da farklılık vardır. Hooper'a göre (2001: 4), erkeklik, erkek olmaktan çok, gücü ve güçlü olmayı ifade etmektedir. Kadınlık, başka bir tanımlamayla dişillik ise erkeklik ve erillikle ilişkilendirilen bu kavramların tersini ifade eder. Kadınlık ve erkeklik ikilemi üzerinden toplumsal cinsiyetin kuruluşunu inceleyen Connell (1995), toplumsal yapı içerisinde iktidar ilişkilerine dayalı olarak şekillenen ve hiyerarşik bir düzlemde işleyen "toplumsal cinsiyet düzeni”nden bahseder. Bu bağlamda tüm dünyada işleyen bir cinsiyet düzeni olduğunu söyleyen Connell (1995: 74) bu düzenin temel dayanağının erkeklerin kadınlardan daha güçlü olması ve onları tahakküm altına alması olduğunu belirtir. Buna göre; hegemonik/egemen erkeklik düzeni erkeklerin baskın, kadınların ise alt sıralardaki konumlarını garanti altına alır; ama bu düzen doğal değil inşa edilmiş bir düzendir (Connell, 1995: 9). Connell, eşitsizlik üzerine kurulan bu temelin "tek yapısal hakikat" oluşturduğunun da altını çizer.

Connell'in tanımını takip edersek; gücün erkeklikle özdeş görülmesi devleti yönetmek, korumak ve temsil etmek görevlerinin de erkeklikle ve eril değerlerle ilişkilendirilmesini beraberinde getirir diyebiliriz. Nitekim uluslararası sistemin güç mücadelesi ve güç dengesi üzerine kurulmuş olması epistemolojik olarak erkeklik tartışmalarıyla uluslararası ilişkiler disiplinini de kesiştirmektedir. Carole Cohn ve Cynthia Enloe (2003: 1192), patriarkal yapının da bu üretilen eril ve dişil değerler gibi doğal olmadığını, her gün yeniden üretilmeye ve devam ettirilmeye ihtiyacı olduğunu söyler. Bu devamlılığı sağlayabilmek için de egemen eril kültür, agresif bir biçimde sosyal olarak yapılandırılır. Aynı zamanda tarihsel değişimlere bağı olarak çeşitli erkeklikler de üretilir (Enloe, 1990: 105). Erkeklikler her toplumda farklı, çoğul, birbiriyle benzeşmez bir yelpaze meydana getirir (Özbay, 2013: 187). Bununla birlikte egemen erkeklik, erkekliğin belirli bir türü olarak diğer erkekliklerden ve elbette kadınlıktan üstün tutulur. 
$\mathrm{Bu}$ farklı erkeklik düzenleriyle mücadele öncelikle birinci dalga feministlerin "kadın temsili" düsturundan feyz alarak kurumları gasp eden erkekliğe yönelik eleştirileriyle gerçekleşmiştir. Diplomatik kurumlar kadın temsilinin en düşük olduğu alanlardan biri olarak uzunca bir süre kadınların katıımına direnmiştir. Aynı zamanda diplomaside erkeklikle özdeşleştirilen kurallar, normlar ve davranışlar normalleştirilirken, kadınlıkla özdeşleştirilen özellikler görmezden gelinmiş ya da normalin dışında tanımlanmıştır. Normali üreten eril diplomatik kültür, feministlerce önce diplomasiye kadınların katııımı arttıılarak dönüştürülmeye çalışılmıştır. Nitekim uluslararası alanda kadının temsiline yönelik adımlar feminizm ile uluslararası ilişkiler disiplini arasındaki bağın gelişmesinde etkili olmuştur (Tür ve Aydın Koyuncu, 2010: 8).

Ancak günümüzde alandaki feminist mücadelenin tek derdi kadınların diplomaside daha fazla temsilini sağlamak değildir. Zira, "toplumsal cinsiyet" kavramı üzerine yapılan ikinci dalga feminist tartışmalarla birlikte öğrendik ki kadın ve erkek arasındaki farklıık biyolojik farklılığın ötesinde tarihsel olarak sosyal ilişkilere içkin bir biçimde şekillenen eril düşünme ve davranış biçimleri bağlamında belirlenen bir farklııktır. Nitekim örnekler de teyit etmektedir ki, bu kültürü dönüştüremediğin sürece kadınların temsilindeki artışı temel alan birinci dalga feministlerin liberal bakışı tek başına kadın-erkek eşitliği adına olumlu bir durumu ifade etmeyebilmektedir. Eril kültürü dönüştürmeye meyletmediğin sürece kadın, eril bir sistem içerisinde, "eril bir özneye” dönüşebilmektedir (Eken, 2017: 454). Nitekim, Connell'in Gramsci'ye referansla kullandığı "egemen erkeklik" (hegemonik erkeklik) kavramını diğer erkeklik tanımlarından (madun-işbirlikçi-marjinal erkeklikler) ayıran en önemli özelliklerinden biri iktidarını "rıza"yı üreterek mümkün kılmasıdır. Bu tür bir eril iktidara rıza göstermek, iktidarın üretimine de katkı sağlamaktır. Diplomasi kurumunda temsil imkanını yakalamış çoğu kadının da bu tür bir rızayı üretmeye katkı sağladığı görülmektedir.

Bugün birinci dalga feminizmin liberal perspektifini takip eden Toplumsal Cinsiyet Eşitliğini Güçlendirme Endeksi (GEM) gibi birçok uluslararası kurum, kadınların fırsat eşitliğinden faydalanma ve karar alma mekanizmalarına katılabilme düzeyini ölçerken rakamları referans almaktadır. Bu çerçevede baktıkları üç temel gösterge vardır: ilki parlamentodaki kadın oranı, ikincisi üst karar ve yönetim 
düzeyindeki kadın oranı ve üçüncüsü de mesleki ve teknik işlerde çalışan kadın oranıdır (Üner, 2008: 10). Rakamlar tek başına olmasa da eril kültürü değiştirmek üzere referans olabilme potansiyeli taşımaktadır. Zira diplomasideki kadın temsilinin artışı ve bunun yapısal olarak diplomasi kültürünün değişimine etkisini değerlendirebilmek için diplomasideki niceliksel ve niteliksel değişime eşgüdümlü bakmak gerekir.

\section{Dış Politikada Kadınların Temsili}

20. yüzyılın ilk yarısında kadınlar dünya politikasında yer almaya başlamış; ama bu konudaki asıl ivme yüzyılın ikinci yarısından sonra yakalanmıştır (Dahlerup, 2001: 104). Özellikle son yirmi yıldır kadınların diplomasiye girmeleri artma eğilimindedir. 20. yüzyılın ikinci yarısının hegemonik gücü olan $A B D$ örneğine baktığımızda, ülkenin dışişleri bakanlığında 1960 yılında yüzde 9.8 olan kadın oranının, 2016'da yüzde 36’ya çıktığını görürüz. ABD özelinde kadınların diplomaside temsilinde bir ilerlemenin olduğu açıktır; ancak 2016'da yapılan bir araştırma, ABD tarihinde görev yapmış tüm büyükelçilerin sadece yüzde 9'unun kadın olduğunu ortaya koymaktadır (Fierman, 2016). Bu da ABD için bir ilerleme söz konusu olsa da tarihsel olarak bakıldığında daha alınacak çok yol olduğunu göstermektedir. Diplomasi tarihinde önemli bir yeri olan İngiltere, kadınların diplomasiye girmesine ABD'den daha geç izin vermiş olsa da günümüzde ABD'den daha iyi durumdadır. Zira birçok ülkenin güvenlik ve stratejik önemi gerekçesiyle kadın diplomat göndermeye çekindiği Ortadoğu'da, İngiltere İkinci Dünya Savaşı sırasında İngiltere Enformasyon Bakanlığı bünyesinde Ortadoğu'nun birçok ülkesinde Freya Stark'1 $1^{5}$ görevlendirmiştir. Hatta Farsça ve Arapça bilen ve oryantalist görüşleriyle bilinen Stark'ın o dönemde İngiliz politikalarına etkisinin, 1946 'da kadınların da dışişleri bakanlığına girebilmesinin önünü açtığı söylenir. Bugüne kadar İngiltere'de Margaret Thatcher ve Theresa May gibi -kadın hareketine oldukça mesafeli de olsalar-iki kadın başbakan olabilmişken, ABD tarihinde henüz hiç kadın başkan olamamışıı. Günümüzde 54 kadın İngiltere adına büyükelçilik görevi yapmaktadır, bu kadınların neredeyse yarısı Avrupa ülkelerinde bulunmaktadır (Wilson, 2017).

\footnotetext{
${ }^{5}$ Freya Stark Türkiye'ye yaptı̆̆ı yolculuktan 1954 yılında yayınlanan Ionia a Quest adlı kitabında bahsetmiştir.
} 
Kadın-erkek eşitliği konusunda Avrupa'da öncü olan İskandinav ülkeleri, diplomaside kadın temsilinde de oldukça ileri bir durumdadır. Örneğin Birleşmiş Milletler Avrupa Ekonomik Komisyonu'nun (UNECE) sunduğu verilere göre İsveç'te bugün diplomatların yüzde 40'a yakını (96 büyükelçinin 38’i) kadındır (UNECE, 2017). Bugüne kadar İsveç'in üç kadın dış işleri bakanı (Laila Freivalds, Ylva Anna Maria Lindh ve Margot Wallström) olmuştur. Son Dış isşleri Bakanı Margot Wallström, İsveç'ın bundan sonra feminist dış politika izleyeceğini söyleyerek bir ilke imza atmışıı (Owens, 2016). Ayrıca 2015-18 yılları arasında İsveç Dışişleri Bakanlığı feminist dış politikası üzerine bir eylem planı oluşturmuştur. Bu eylem planına göre İsveç Hükümetinin dış politikaya dair altı öncelikli alanı bulunmaktadır: hukuk kurallarını artırmak, desteklemek ve geliştirmek; toplumsal cinsiyet temelli şiddet ve cinsel şiddetle mücadele etmek; cinsel ve üreme sağlığı haklarını korumak; kadınları ekonomik anlamda güçlendirmek; sürdürülebilir kalkınmayı desteklemek ve barış süreçlerine kadınların katııımını artırmak (Biter, 2017: 512). İsveç ayrıca nasıl feminist bir dış politika izlenebileceği konusunda diğer ülkeleri bilgilendiren bir kılavuz da hazırlamıştır (dw.com.tr, 2018).

UNECE'nın rakamlarını referans alarak devam ettiğimizde İsveç’i yüzde 35 kadın diplomatla (71 büyükelçinin $2{ }^{`}$ i) İrlanda’nın takip ettiğini görürüz (UNECE, 2017). Türkiye UNECE'nin listesinde 11. sıradadır. Türkiye'nin arkasından İsviçre, Gürcistan, İtalya, Ermenistan ve Kazakistan gelmektedir. Kazakistan'ın 58 büyükelçisinden sadece biri; Ermenistan'ın 40 büyükelçisinden sadece üçü kadındır. Bir Avrupa ülkesi ve Avrupa Birliği (AB) kurucu üyesi olarak Italya'da da durum çok iç açıcı değildir. İtalya'nın 215 büyükelçisinden sadece 17'si kadındır (UNECE, 2017). Bölgesel olarak baktığımızda yüzde 35 ile İskandinavya en fazla kadın büyükelçi bulunduran bölgeler arasında en ön sıradadır. Bunu yüzde 25 ile Kuzey Amerika ülkeleri, yüzde 18.6 ile $A B$ üyesi ülkeler ve yüzde 17 ile Afrika ülkeleri takip etmektedir. Ortadoğu ise yüzde 6 ile en düşük orana sahiptir (Süleymanoğlu Kürüm ve Rumelili, 2018: 10).

Ortadoğu sadece kadın diplomatların çok az olduğu bir bölge değil; daha önce de belirtildiği üzere aynı zamanda Batı ülkelerinin de kadın diplomat bulundurmak istemedikleri bir bölgedir. Kadın diplomatların bu bölgede görevlendirilmemesi genellikle bölge ülkelerinin muhafazakârlığı ve bunun cinsiyet ilişkileri üzerindeki 
etkileri üzerinden açıklanmaktadır. Ülkelerin bu durumu kimi diplomatik krizleri de beraberinde getirmiştir. Örneğin 2014 yılında İtalya Dışişleri Bakanı Emma Bonino, İran'a girerken başını kapatmak istememiş; ama İran bunu kabul etmeyince ikna edilmek üzere bir süre geldiği uçakta beklemiştir. Benzer şekilde Avusturya Dışişleri Bakanı Julia Bishop da feministler tarafından çokça eleştirilmesine rağmen, en sonunda direnememiş şapkaya benzer bir aksesuarla başını kapatarak İranlı yetkililerle görüşmüştür (Doostar, 2015). Benzer bir deneyim feminist dış politika stratejileriyle bilinen İsveçli kadın diplomatlarca da yaşanmıştır. İranlı yetkililerle başı kapalı görüşen İsveçli kadın diplomatlar feministlerce eleştirilmiştir (bbc.com, 2017). Ancak zaman zaman Ortadoğu ülkelerine ilişkin muhafazakârlık etiketi, ülkeden bağımsız batılı erkek mevkidaşları tarafından kadınları dışlamanın bir gerekçesi olarak da kullanılabilmektedir. Örneğin, Ortadoğu ülkelerinde görev yapmış diplomat kadınlar, bulundukları ülke temsilcilerinden önce kendi Amerikalı mevkidaşları tarafından dışlandıklarını ifade etmişlerdir. Arap bölgesinde uzun bir kariyere sahip olan Andrea Farsakh, davetli olmasına rağmen Amerikalı erkek amirlerinin Suudi davetlileri rahatsı etmemek için kendisine davetlerde yer vermediğinden bahsetmiştir (akt. Toosi, 2014). Oysa Suudi Arabistan'da kutsal yerler dışında, İran'da olduğu gibi diplomatik temsilcileri de içeren örtünme gibi herhangi bir zorunluluk yoktur (dusuncemektebi.com, 2018). Batı ve doğu arasında oryantalist perspektifin kurduğu hiyerarşik ilişki ve cinsiyetler arası ilişkilerin buna eklemlenme biçimi bu kez de diplomasi kurumu üzerinden tezahür eder. Nitekim kadınların din gerekçesiyle dışlandığı tek yer Ortadoğu değildir. Vatikan'ın da bu konuda oldukça muhafazakâr bir yaklaşıma sahip olduğunu, 1970 yılında Batı Almanya'nın atamayı önerdiği elçiyi kadın olduğu için reddettiğini hatırlamak gerekir (İskit, 2015: 174).

Türkiye diplomaside kadınların temsili konusunda gelişmiş ülke standartlarının çok gerisinde değildir. Hatta kadın diplomat sayısı sürekli artma eğilimindedir. 2002 yılında Türkiye'nin kadın büyükelçi sayısı 14 iken, bu sayı 2012'de 22'ye, 2016'da 37'ye, 2017'de 43'e ve en son 2018 yılında 63'e çıkmıştır (Demirci ve Yüzbaşıoğlu, 2019). Aynı dönemde, Türkiye'nin dış temsilciliklerinin sayısı da 163 'ten 242 'ye çıkmışıı. ${ }^{6}$ Temsilcilik sayısının artmasına paralel olarak kadın diplomatların ataması da artmıştır. Yine aynı yıllarda kariyer memur sayısı da 575'ten 622'ye (merkezde

${ }^{6} 142$ büyükelçilik, 85 başkonsolosluk, 13 daimi temsilcilik, 1 ticaret ofisi ve 1 konsolosluk 
263, yurt dışında 359) yükselmiştir. Yurt dışında bulunan kadın misyon şefi sayısı 37 olmuştur; bunun altısı siyasi atama yoluyla belirtilen pozisyonlara gelmiştir. Son yıllarda Türkiye'de Dışişleri Bakanlığı bünyesinde kadınların önceki yıllara göre daha fazla istihdam edildiğini rakamlar teyit etmektedir. Ancak birçok kuruma benzer şekilde büyükelçilik gibi itibarlı pozisyonlara gelindiğinde kadınların temsilinin oranı alt görevlerdeki sayıların altına düşmektedir. Bu bulgu, cam tavan sendromunun diplomatik kurumlarda hala işlediğini ve kadınların daha az itibarlı pozisyonlarda kümelendiğini göstermektedir (Süleymanoğlu Kürüm ve Rumelili, 2018: 12).

Bu kümelenmenin bir başka veçhesi de kadın büyükelçilerin bir devlet için stratejik olarak çok da önemli olmayan ülkelere atanmalarıdır. Örneğin Türkiye adına görevli olan hiçbir kadın büyükelçinin Türkiye ile yoğun diplomatik ilişkileri olan ABD, Almanya, İngiltere ya da Fransa, Rusya gibi ülkelere atanmadıkları, ya Doğu Avrupa'da daha küçük ülkelere ya da Afrika ülkeleri gibi zayıf diplomatik ilişkilerin olduğu ülkelere atandıkları görülür (Demirci ve Yüzbaşıŏlu, 2019). Erkek egemen kültür bu defa da atama yapılan mekânları cinsiyetlendirerek kadın temsilini mümkün kılar. Ann Towns ve Birgitta Niklasson da (2016), diplomaside kadın ve erkeklerin rollerini incelerken; kadın ve erkeklerin güç ve itibar açısından farklı yerlere atandığını tespit etmiş̧ir. Fakat, son dönemde istisna örneklerle de olsa bunda bir değişme eğilimi vardır. Örneğin 2014 yılında Raife Gülru Gezer'in, Türkiye'nin Los Angeles Başkonsolosu olarak atanması önemlidir. 29 yıllık meslek hayatının 10 yılını Kuzey Atlantik Antlaşması Örgütünde (NATO) ulusal güvenlik, askeri ve siyasi konular üzerine geçiren Lebibe Gülhan Ulutekin ise Avrupa Genel Müdürü olarak görev yapmıştır (Süleymanoğlu Kürüm ve Rumelili, 2018: 15). Günümüzde NATO’ya üye ülkeler içinde 13 savunma bakanı da kadındır (star.com.tr, 2018). Son olarak Almanya Savunma Bakanı Ursula von der Leyen'in, 60 yıl sonra Avrupa Komisyonu'nun ilk kadın başkanı olarak seçildiğini belirtmek gerekir.

Tüm iyileşmelere rağmen, dünya ortalamasına baktığımızda halen büyükelçilerin yüzde 85'inin erkek olduğunu görürüz (Towns ve Niklasson, 2016: 17). Yine de kadınların diplomatik kurumlardaki temsilinin arttığı açıktır. Tüm ülkelerde birbirine paralel gelişen bu eğilimin arkasında Birleşmiş Milletler Güvenlik Konseyi'nin 2000 yılında aldığı, kadınların dış politikada karar alma sürecine daha fazla katııımını sağlamaya dönük bir kararın bulunduğu söylenebilir. Güvenlik Konseyi'nin 1325 sayılı 
bu kararı, özellikle silahlı çatışmaların kadınlar ve kız çocukları üzerindeki olumsuz etkilerinden (evlerinden çıkartılmak, iltica etmek zorunda bırakılmak gibi) yola çıkarak çatışmayı çözme ya da barış süreci gibi tüm karar alma mekanizmalarına kadınların daha fazla katılımını hedefler (bm1325eylemplani.org). Ayrıca, kadınların çatışmalar süresince ve sonrasındaki haklarını koruyan uluslararası insancıl hukuk ve insan hakları hukukunun tamamen uygulanmasının gerekliliğine de kararda değinilmiş, barışı koruma operasyonlarında toplumsal cinsiyetçi bakış açısının egemen kılınması gereğinin altı çizilmiştir (Aydın, 2011: 109). Elbette bu değişiklikte insan hakları, kadın hakları, barış ve güvenlik konularını temel alan uluslararası organizasyonların 1990'lardan bu yana kadınların karar alma mekanizmalarında temsilini arttırmaya dönük çabaları ve bu anlamda uluslararası örgütler ve devletlere yaptıkları baskının etkisi büyüktür. Bu niceliksel temsildeki artışın diplomasi kültürünün yapısal olarak değişimine nasıl etkisi olduğu ise ayrıca tartışılması gereken bir konudur.

\section{Kadın Temsilindeki Artış Eril Kültürü Dönüştürür mü?}

Son dönemde, feminist tartışmaların uluslararası ilişkiler disiplini üzerinde etkisinin artmasıyla birlikte, diplomaside kadının yerini ele alan birkaç önemli eser yayınlanmıştır (McCharty, 2014; Sluga, James vd., 2015). Bu çalışmalarda görülmektedir ki modernleşme öncesi dönemde az sayıda da olsa bazı kadınlar diplomatik ilişkilerin yürütücüsü olarak etkin roller üstlenmiş ve inisiyatifler almışlardır. Oysa diplomasinin eril bir niteliğe bürünmesi ve kadınların bu alandan neredeyse tamamen dışlanması diplomasinin modern bir yapı olarak kurumsallaşmasıyla, yani meslek haline dönüşmesiyle mümkün olmuştur. Bu nedenle 20. yüzyılın başına kadar kadınların diplomaside temsili gayri-resmi rollerle sınırlı kalmıştır. İlk kadın misyon şefi, Aleksandra Kollontay sosyalist rejim döneminde Sovyetler Birliği tarafından 1923 yılında Norveç'e atanmıştır. 1945 yılına kadar çeşitli ülkelerde büyükelçilik yapan Kollontay, daha sonra Sovyetler Birliği'nde Dışişleri Bakanlığı'nda da görev almıştır (gazetekarinca.com, 2017). ABD'de ise kadınlar Dışişleri Bakanlığı'na 1925'ten itibaren kabul edilmeye başlanmıştır. ABD’nin, Danimarka'ya ilk defa elçi olarak bir kadın göndermesi 1933'de mümkün olmuştur. Fransa 1930'da Dışişleri Bakanlığı'na giriş sınavlarını kadınlara da açmış, ancak misyon şefi olarak atamamıştır. 
İngiltere'de ise 1947 yılına kadar herhangi bir kadın diplomat ataması yapılmamıştır (Barker, 2009).

Türkiye'de diplomaside kadınların temsil edilebilmesinin tarihi, dünya örnekleriyle uyumludur. Türkiye'nin ilk kadın diplomatı Adile Ayda 1932 yılında bakanlığa girmişsir. Ayda, 1967 yılında Roma Büyükelçiliğine atanmıştır (listelist.com). Ayda, atama yoluyla diplomat olmuştur. Dışşşeri Bakanlığı'nın ilk kariyer diplomatı kabul edilen Filiz Dinçmen ise 1968-1970 yılları arasında Türkiye Tahran Konsolosluğu'na atanmış, daha sonra 1982'de Hollanda Lahey Büyükelçisi göreviyle Türkiye'nin ilk kadın büyükelçisi unvanını almıştır. 1984 yılında Strasbourg'da Avrupa Konseyi Türkiye Daimi Temsilcisi görevine getirilen Dinçmen, 1988 yılında Dışişleri Bakanlığı'nın ilk kadın müsteşar yardımcısı olmuştur. Dinçmen aynı zamanda 2001-2004 yılları arasında Vatikan'da ilk kadın Müslüman büyükelçi olma görevini de üstlenmiştir.

Fakat kadınların diplomat olmaya başlamaları, bir eşiğin aşılması anlamına gelse de sorunun çözüldüğü anlamına gelmemiştir. Zira bu defa da kadınlar görev yerlerinin niteliği ve cinsiyetleri dolayısıyla yazılı ya da yazısız kurallara dayanarak uygulanan ayrımcılıkla baş etmek zorunda kalmışlardır. Örneğin, ABD'de sır tutamayacakları, erkekler kadar "etkili" diyalog kuramayacakları, duygularıyla hareket edecekleri ve fiziksel riskleri karşılayamayacakları gibi gerekçelerle kadın diplomatların ilerlemeleri uzunca bir süre engellenmiştir (Bashevskin, 2018: 47). Benzer deneyimler Türkiye'deki kadın diplomatlar için de söz konusu olmuştur. Türkiye'nin üçüncü kadın büyükelçisi Solmaz Ünaydın, kendisiyle yapılan bir görüşmede, diplomasiye girmek ve etkili olabilmek için mezun olunan lisenin Galatasaray, üniversitenin Mülkiye ve cinsiyetin de erkek olmasının neredeyse şart olduğunu söylemiştir. Aynı görüşmede Ünaydın, giriş mülakatlarında kadın adayların erkeklerin üç katı süre içeride tutulduklarını, terfileri ise kadınların erkeklerden en az iki kat fazla çalışarak kazandıklarını belirtmiştir (akt. Pamir, 2006). Öte yandan 1969 yılında Dışişleri Bakanlığı'na giren ve o dönemde bakanlıkta çalışan yedi kadından biri olan Sumru Noyan da kendisiyle yapılan bir söyleşide "O dönemde kadınları bu göreve almak istemiyorlardı" (cocukdayaparimkariyerde.com) diyerek Ünaydın'ın iddialarını teyit etmiştir 
Sumru Noyan'la yapılan görüşmedeki ifadeler sadece bakanlığa giriş sürecinde yaşanan ayrımcılıkla ilgili değil; aynı zamanda kadınların kuruma girdikten sonra kendilerine yönelik eril baskıyla nasıl baş ettiklerine ilişkin de önemli ipuçları vermektedir. Görüşmenin devamında Birleşmiş Milletler Uyuşturucu ile Mücadele ve Suçun Önlenmesi Dairesi Başkan Yardımcılığı yaptığı dönemde uyuşturucu ticareti yapılan tüm ülkelere gittiğini belirten Noyan'ın, deneyimlerini aktarırken kullandığı kelimeler ve vurguları daha önce söz ettiğim "eril değerler içinde kadının kendini ispat çabası"na neden olan eril baskının bir tür yansıması gibi:

Afganistan, Pakistan ve İran'ın en ücra noktalarını ateş altında iken dolaştım ve bu bölgelerde görev yaptım. Bir defasında Kandahar'da toplantı yaptığımız bir bina 10 gün önce müttefikler tarafından bombalanmıştı. Görevim gereği, insan hakları ihlalleri ile gündeme gelen ülkelerin neredeyse tamamına gittim. Gittiğimiz ülkelerde zor şartlara ve karşılaştığımız engellemelere rağmen görev yaptım. BM mavi bayrağı ile görev yapmanın mutluluğunu her zaman yaşadım. (cocukdayaparimkariyerde.com)

V. Spike Peterson ve Anne Sisson Runyan'ın da belirttiği üzere, uluslararası ilişkilerde geleneksel algı, "dış politika alanında siyasi olarak güçlülüğün erkek gibi olmayı gerektirdiği”" yönündedir. Bu algı alanın egemen eril yapısını da pekiştirmektedir (Peterson ve Runyan, 1993: 71). Nitekim Noyan yukarıda alıntılanan sözlerinde en az bir erkek kadar cesur davranarak görevini icra ettiğini ima etmektedir. Benzer bir ima, bir diğer kadın büyükelçi Solmaz Ünaydın'ın ifadelerinde de yer alır:

Zoru başarırsam istediklerime daha kolay ulaşırım diye düşündüm. Beni kimse zorlamadı, ben hep zoru seçtim. Bana kadın muamelesi yapılmasını da istemedim. Hep erkeklerle eşit olmayı, onlarla aynı koşullarda çalışma hatta daha ağır sorumluluklar yüklenmeyi seçtim. (akt. Pamir, 2006)

Öyle görünüyor ki diplomat kadınlar, kurum içinde yer edinebilmek ve terfi edebilmek için kendilerini "ispat etmek" zorunda olmanın baskısı altında eziliyorlar. Dolayısıyla diplomasideki eril kültürün kadınlara yönelik görünmeyen buyrukları, kadınları erkeklerden daha farklı bir mücadeleye zorluyor. Erkekler gibi kadınlar da eril değerleri ele geçirmenin, ona benzemenin ya da en azından ona yaklaşmanın 
menfaatlerine olacağına inanıyor, kültürel dolayımla buna inanmaya çağrılıyor, ikna ediliyor (Özbay, 2013: 186). Zira kültür bize normalin ne olduğunu söyleyen ve bizi normalleştiren normlar bütünüyse; kabul gören ve takdir edilen ne ise ona göre davranmak da doğal olan olarak kabul edilir. Nihayetinde egemen kültüre dahil olan da o kültürün sınırları içinde konuşur, temsilini o "doğal" sınırlarla mümkün kılar. O nedenle, kadın yine farkında olmayarak kendi varlığını eril bir söylemin devamı şeklinde tanımlayabilir. Nitekim, Ünaydın'ın "bana kadın muamelesi yapılmasını istemedim" ifadesi, esasında kendisinin de diplomasiyi bir erkek alanı olarak gördüğünü de teyit ediyor. İlk kadın büyükelçi Adile Ayda'nın da benzer bir ifadesi var: "Ben artık kadınlıkla erkekliği bir arada yürütmeye çalışıyorum" (Akt. Sülemanoğlu Kürüm ve Rumelili, 2018: 14). Bu iki ifade Alman ekspresyonist ressam Hans Hoffmann'ın, bir diğer ekspresyonist ressam Lee Krasner için de söylediği "Krasner'in resimleri o kadar iyi ki, insanın onların bir kadın tarafından yapıldığına inanası gelmiyor!" (akt. Berktay, 2012) cümlesini hatılatıyor. Öyle görünüyor ki kadınlar, kadın olmayı vurgulamadan diplomaside var olmaya çalışıyor.

Ancak bu defa da kadınlar açısından eril kültür içinde ikinci sorun ortaya çıkıyor: "Erkekler kadar iyi olmak, kadınların evlilik ve aile sorumluluklarına ilişkin bir inmal yaratır mı?" Zira eril sistemin kadın olmaya ilişkin neredeyse tek vurgusu aile bağlamı içinde şekillendiği için, bu anlamda diplomat kadınların sorunlarının içeriği de ona göre belirleniyor. Nitekim diplomaside evlilik konusundaki baskı ve engeller de kadınlar açısından ciddi sorunlar yaratıyor. Illk aşamada kadının aile (özel) ve iş (kamusal) arasında denge sağlayamayacağı endişesi ve yargısı dolayısıyla 1970'lere kadar batı ülkelerinin önemli bir çoğunluğunda kadın diplomatların evlenmesi yasaklanıyor. Evlilik engeli ABD'de 1972 ve İngiltere'de 1973 gibi oldukça geç bir dönemde kaldırılıyor. Kadın diplomatların önündeki evlilik engeli diplomasi kurumunda kadınların kariyerlerinde ilerlemeleri ile evlilik arasında karşıt bir ilişki kurulduğunu gösteriyor. Oysa erkek diplomatlar açısından evlilik ve eşlerinin diplomatik misyonlarda "tamamlayıcı" olarak üstlendikleri roller olumlanıyor, hatta eş seçimi diplomatik misyon atamalarında belirleyici dahi olabiliyordu. $O$ nedenle günümüzde Avrupa Komisyonu başkanlığına seçilen Ursula von der Leyen'le ilgili sıkça yapılan "evli ve yedi çocuk annesi" vurgusu alt metninde "evli ve çocuk sahibi kadın kariyer yapamaz" varsayımına karşı bir itirazı da içeriyor. 
Türkiye'de diplomat kadınlar açısından bazı koşulların batıdaki birçok ülkeden daha iyi olduğu söylenebilir. Örneğin, batıdaki deneyimlerin tersine Türkiye'de sadece belli bir dönem kadınların yurt dışı misyonlarında görevlendirilmeleri yasaklanmıştır. Türkiye'nin ilk kadın diplomatı Adile Ayda görevini ancak iki yıl sürdürmüş, sonrasında ise kadınların yurt dışı temsilciliklerine atanmasının yasaklanması nedeniyle 1957 yılına kadar diplomatik kariyerine dön(e)memiştir (Süleymanoğlu Kürüm ve Rumelili, 2018: 13). Fakat batıda olduğu gibi diplomat kadınların evliliğinin yasaklanmasına ilişkin herhangi bir düzenleme Türkiye'de hiçbir zaman resmi olarak uygulanmamıştır. Yine de bir dönem uygulanan ve diplomat eşlerinin yurt dışındayken "diplomatlık" dışında bir meslek icra edemeyeceğini öngören kural, kadın diplomatların hem evlenip hem de dış misyonlarda görev alabilmelerinin önünde bir engel oluşturmuştur (İskit, 2015: 175). Kadınların diplomat olarak görev almaları niceliksel olarak artsa da, Türkiye'de genel geçer algı hala diplomatların "erkek" ve eşlerin de "kadın" olduğu yönündedir. Nitekim diplomat eşlerinin kendi aralarında kurdukları Dış Işleri Mensupları Eşleri Dayanışma Derneği hala sadece kadınlardan oluşur. Oysa İngiltere'de Diplomasi Mensuplarının Karıları Derneği (Diplomatic Services Wives Association) adını 1990 yılında Diplomat Eşleri Derneği (Diplomatic Spouses' Association) olarak değiştirmiştir (Stanley, t.y.).

Öyle görünüyor ki eril sistem, iç/dış ayrımı üzerinden kadının evde erkeğin dışarda olmasını normalleştirdiği, bunun tam tersini ise marjinalleştirdiği için yazılı bir kural olmasa dahi kendiliğinden kadınların önemli bir kısmı evliliklerini "tercih edip" dış görevleri talep etmemektedir. Daha önce sözünü ettiğimiz toplumsal cinsiyet düzeni içinde aile birlikteliğinin sağlanması ve korunması misyonunu kadına yükleyen cinsiyetçi normlar, kadınların yükselmesi önünde görünmez engeller oluşturmaktadır. Kadınlar için bu durumun ikinci alternatifi kurum içinden, yine bir diplomatla evlenmektir. Ancak bu defa da diplomat çiftlerin aynı yere atanması sorunu ortaya çıkmaktadır. Bu nedenle diplomat çiftler birbirinin astı ve üstü olmasın diye çiftleri farklı misyonların bulunduğu büyük başkentlere atamak ya da yakın ülkelere atamak şimdilik bir usul olarak işletilmektedir (İskit, 2015: 175). Ancak 1960-1998 yılları arasında uygulanan bir kurala göre çiftler birden fazla aynı görev yerinde bulunamıyordu, bu dönemde eşleri lehine izin alan ya da görevini bırakanlar çoğunlukla kadınlardı. İlk kadın büyükelçilerden Filiz Dinçmen de 1998'e kadar 
yürürlükte olan bu düzenleme nedeniyle kendisi gibi diplomat olan eşiyle bir süre ayrı yaşamak zorunda kalmıştır. Fakat Dinçmen, mesleğini bırakmamış ve büyükelçiliğe kadar yükselerek döneminin istisna kadınlarından biri olmayı başarabilmiştir.

Eril diplomasi kültüründe kadın temsilinin iki türünün olumlandığını söyleyebiliriz. Biri kadınların kendilerine atfedilen dişil rolleri sürdürmeleri; diğeri ise eril kültür içinde rol alan kadınların da bu kültüre uygun bir biçimde eril bir tutum sergilemeleridir. İlkine ilişkin verebileceğimiz belki de en iyi örnek ABD'deki first ladylik (başkanın eşi) makamıdır. Amerikan siyaseti erkekler için başkanlık ve kadınlar için de başkan eşi olmayı (first lady) öngören oldukça cinsiyetçi bir ayrıma dayanmaktadır. First lady'ler genelde resmi düzeyde olmasa da daima toplumsal ve siyasal roller üstlenirler (Yelsalı Parmaksız, 2016: 569). Bu siyaset geleneğine yönelik tabu yıkıcı ilk isim, feministler tarafından çokça eleştirilmesine rağmen Hillary Clinton'dır (Ataç, 2017: 82). 1993-2001 yılları arasında Bill Clinton'ın Başkanlık döneminde first lady olan Hillary Clinton, 2009-2013 yılları arasında Barack Obama Başkanlığı döneminde Dış İşleri Bakanlığı yapmış, 2016 yılında da ABD'de Başkanlık için Demokrat Parti'nin adayı olarak yarışmıştır. Aynı zamanda Clinton, ABD tarihinde ana akım partilerin gösterdiği ilk kadın başkan adayıdır.

First lady olmaya benzer bir diğer statü de "diplomat eşi" olmaktır. Diplomat eşi olmak diplomat erkeği "tamamlayan" gayri-resmi diplomatik bir misyon olarak sayılır. Her ne kadar oldukça tartışmalı ve ikincil de olsa, dünya siyasetinde kadınlar arabulucu, bilgi toplayıcı (Sluga, Calvi ve James 2015), ya da ajan olarak çeşitli biçimlerde kullanılmışlardır (Enloe, 1990; Lamaothe, 2014). Ayrıca yönetici üzerinde kan bağı ya da evlilik yoluyla etkisi olan, böylece dolaylı olarak dış politikayı etkileyen kadınlar da vardır. Osmanlı İmparatorluğu'nda Hürrem, Nurbanu, Safiye ve Kösem Sultanlar gibi örnekler bu türden ilişkileri saraydan yürüten kadınlar olarak tarih yazınında yer almışlardır (Peirce, 1993: 219). Erkek iktidarıyla eşlik ya da kan bağı yoluyla kurulan, siyasal olarak güç ilişkilerine yakın duran bu kadınlık durumu feministlerce çokça eleştirilmektedir. Ancak eril tarih yazını kadınların diplomaside ikincil rollerini olumlayan bu tür örneklerle doludur. 19. yüzyıldan itibaren Ingiltere'de erkek diplomatlar seçilirken, davetler düzenleyerek elçilik personeline moral olarak destek verecek "zarif" eşleri olanların tercih edildiği dahi söylenmektedir (McCarthy, 2014a ve 2014b). 
20. yüzyıla gelindiğinde kadınların eş olarak gayri-resmi görevleri önceki döneme benzer bir biçimde devam eder. Kadınlar, diplomat eşleri olarak bulundukları yerlerde sosyal çevre oluşturur, sosyal faaliyetlere katılır, davetler verir ve zaman zaman da bu sosyalleşmenin bir çıktısı olarak bilgi toplar. "Diplomat eşi" sıfatıyla kadınların yaptığı görevler, özel alan ve kamusal alan arasında kurulan hiyerarşik düzende özel alanın bir devamı olarak görüldüğünden oldukça değerli bulunur. Ancak diplomat eşleri diplomasiye yaptıkları bu "katkı" dolayısıyla ne bir ücret alırlar ne de diplomatların başarıları onları da dahil edecek şekilde takdir görür. Carol Pateman'ın da vurguladığı üzere (1988), her iki tarihsel dönemde de ideal diplomat eşi kavramı, kadınların ancak ataerkil sınırlar içinde var olabildiğini gösteren bir duruma işaret eder.

Bu tür cinsiyetçi mekânsal (özel ve kamusal alan) ayrışmalara ya da kadınların "tamamlayıcı" unsur olarak görülmelerine sadece diplomat ailelerinde değil, kurumsal olarak diplomaside de tanık olunur. Toplumsal cinsiyet normlarının sosyal ve siyasi örgütlenmeler içinde kurumsallaştığını ifade eden "cinsiyetçi kurumlar" kavramı, kurumlarda kadınlar ve erkekler için uygun görevlerin cinsiyet sembolleri ve normları aracılığıyla belirlendiğini söyler (Acker, 1990). Örneğin diplomaside kadınlar çoğunlukla erkeklerin görev aldıkları pozisyonlara yardımcı konumlarda çalışmaktadır. Ancak sadece roller değil, dış politikaya ilişkin konular da dişilleştirilebilmekte ve bu dişil alanlarda kadınların varlığı meşru, kabul edilebilir bulunmaktadır. Kadınların uyuşmazlıkların çözümüyle ilgili görevlerin yanı sıra birlik beraberliği inşa etme, kırsal bölgelerin geliştirilmesi, uluslararası çevre sorunları ve barış gibi yumuşak (soft politics), bu nedenle de dişil kabul edilen politika alanlarıyla ilgilendiklerinin varsayılması, geleneksel olarak güçlü bu nedenle de eril kabul edilen ulusal güvenlik (özellikle askeri boyutu), ekonomik rekabet ve çatışma gibi sert politika (hard politics) alanlarının dışında tutulmaları buna örnek olarak verilebilir (Peterson ve Runyan, 1993: 69). Zira belirlenen dişil ve eril alanlar arasında bir hiyerarşi vardır ve dişil alanlar bu hiyerarşide en altta yer alır. Üstelik egemen eril kurumlarda kadınlara, kariyerlerinde kendilerine karşıt görünmez bir el gibi işleyen "cam tavan" engelini ancak erkeksi özellikler sergileyerek aşabilme imkânı tanınır (Morgan, 1989). 
Bu noktada kadının eril kültür içindeki temsilinin ikinci unsuruna; yani eril kültür içinde rol alan kadınların da bu kültüre uygun bir biçimde eril bir tutum sergilemesinin beklenmesi meselesine gelebiliriz. Örneğin savaş kararını verenler çoğunlukla erkekler olmasına rağmen bunun istisnası olan Golda Meir, Margaret Thatcher ve Condelizza Rice gibi karar verici kadın örneklerinde de egemen eril değerlerin ötesine geçilemediği, hâkim olan erkek egemen sistemin devam ettirildiği görülmüştür (Tür ve Aydın Koyuncu, 2010:13). En son İngiltere'de Theresa May de, kadınların iş birliğine daha yatkın olduğu varsayımının tersine Brexiti destekleyen; yani İngiltere'nin $A B$ içinde kalmasını istemeyen isimlerden biriydi. Bu örneklere tarihten uluslararası politikada etkili bir isim olarak Eski Mısır'da Cleopatra, Bizans Imparatoriçesi Theodora, İngiltere'de uzunca iktidarda kalmış olan Kraliçe I. Elizabeth ya da kolonileştirme siyasetinin önemli ismi Kraliçe Victoria veya Rusya'nın dünyada önemli bir aktör olmasını sağlayan Catherina'yı da ekleyebiliriz (Peterson ve Runyan, 1993: 46-47). Öte yandan Birleşmiş Milletler (BM), AB veya Avrupa Konseyi gibi uluslararası örgütlerde çok az sayıda kadın aktör yer almasına rağmen bu kurumlardaki kadınların da büyük kısmının, kendilerinden beklenenin tersine çoğunlukla eril sistemin normlarına uygun davrandıkları veya bu tür kararlara imza attıkları bilinmektedir (Aydın Koyuncu, 2011: 100).

Daha önce sözünü ettiğimiz, Avrupa Komisyonu'nun başkanlığına seçilmesinin kadınlar açısından heyecanla karşılandığı bir isim olan Alman Ursula von der Leyen, uzun süre savunma bakanlığı yapmış ve $A B$ nezdinde bir ordu kurulmasını öneren bir isimdir. Kasım 2019 tarihinde görevi Jean Claude Juncter'den devraldığında Avrupa Komisyonu'nun ilk kadın başkanı olacaktır. Ancak bugüne kadarki güvenlik ve güç odaklı savunularına bakarsak, bu başarının feminist hareket açısından nasıl bir anlam taşıdığı oldukça tartışmalıdır. Örneğin Leyen, NATO'nun 60. kuruluş yıldönümünde, feminist düşünürlerin beklentilerinin tersine NATO üyelerini daha fazla savunma harcaması yapmaya davet etmiştir (dw.com.tr, 2015). Türkiye'de 1996-97 yıllarında dışişleri bakanlığı ve 1993-96 yıllarında başbakanlık yapmış olan Tansu Çiller de bu örneklerden biridir. ${ }^{7}$ Türkiye Kuzey Irak'a yönelik 1995 yılındaki Çelik Harekatı, 1997 yılındaki Çekiç ve Şafak Harekatları gibi kapsamlı askeri

\footnotetext{
7 Dünyada karar verme mekanizmalarında yer edinen kadınlara ilişkin daha fazla bilgi için bkz. http://www.guide2womenleaders.com/women_state_leaders.htm\#T
} 
operasyonları Çiller'in Başbakanlık ve Dış İşleri Bakanlığı yaptığı dönemlerde gerçekleştirilmiştir.

$\mathrm{Bu}$ örnekler kadınların barışa, çatışmaların çözümüne daha yatkın olduğu varsayımını temel alan özcü yaklaşımları doğrulamamaktadır (Tickner, 1997: 613). Mary Caprioli ve Mark A. Boyer kadın liderlerin karar alma sürecindeki yaklaşımlarını feminist perspektiften ele aldıkları çalışmalarında, krizleri çıkaranların ilk aşamada kadın karar vericiler olmamakla birlikte kriz süresince şiddetin kullanılmasına karar vererek sert önlemleri uygulayabildiklerini tespit etmişlerdir (2001: 503-518). Bunun nedenleri üzerine de düşünen Caprioli ve Boyer, sosyal olarak erkek merkezli bir politik çevrede kadınların erkek rakiplerine göre daha saldırgan bir politika izlemek ihtiyacı hissetmiş olabileceklerini söylerler. Böylece kadınların, özellikle tehdit anında bir devletin karar vericisi olarak kendilerini kanıtlama çabası içine girebildiklerini iddia etmektedirler. Bu ispat çabası ve kendini eril değer yüklü dış politikada kabul ettirme gayreti kadınları da eril kültüre uygun hareket etmeye zorlamaktadır. Eril kültür içinde kadınlar iki seçenek arasında sıkışıp kalmaktadır. Bu seçeneklerden ilki kadınların barışçıl politikalar izlemeleridir; ama bu onları sistemsel olarak zayıflatmakta ve dışlanmalarına neden olmaktadır. İkinci seçenekte kadınlar sisteme dahil olabilmek için zorunlu olarak eril bir şekilde tanımlanan kuralları taklit etmektedir. Öyleyse, tekrara girmek riskini göze alarak yeniden altını çizelim: mesele sadece dış politikada, diplomaside kadınların daha fazla temsilini sağlamak değildir; aynı zamanda var olan eril sistemin sorunlarının aşılması ve değiştirilmesidir. Bu değişim ancak bu sistemi normalleştiren eril kültürün kökenlerinin hem kadınlar hem erkekler tarafından feminist bir sorgulanmasının yapılmasıyla mümkün gözükmektedir. Aksi taktirde, sisteme dahil olan kadınlar da egemen eril değerlere rıza göstererek sistemin değişmez kılınmasına katkı sağlayabilmektedir.

\section{Sonuç}

Diplomasi kurumlarındaki sayısal değişimin yapısal değişime yansımaları her zaman oldukça gerilimli olmuştur. Yapısal değişimin gerçekleşebilmesi ancak kadınların uğradıkları ayrımcılığı fark edebilmeleri ve bunu sorgulamalarıyla mümkündür. Ancak bu noktadan sonra kadınlar, değişim yönünde bir irade gösterebilirler. Diplomatik 
kurumlardaki kadınların politika üretme biçimine baktığımızda, bu konuda iyimser olmak pek mümkün değildir. Kadın diplomatların pratikleri eril sistemi sorgulamanın ya da değiştirmenin ötesinde çoğunlukla bunu tekrar etmeye dönüktür. Diğer taraftan yapısal değişiklikler için gerekli olan diğer koşul, konunun öznelerini yani kadınları güçlendirecek hukuksal düzenlemelerin yapılmasıdır. Nitekim BM'nin aldığı kararlar, başta $A B$ ve Avrupa Konseyi olmak üzere bölgesel örgütlenmelerin kurumlarda kadın temsilini arttırmaya dönük teşvikleri kadınları ve erkekleri dış politika kültüründe egemen olan eril yapının dönüştürülmesi konusunda zorlamaktadır. Bu zorlamada uluslararası ilişkiler disiplini içinden konuşan feminist düşünürlerin önemli bir etkisi vardır. Dış politikanın eril yapısına rağmen, feminist düşünürlerin devlet, güvenlik, güç, anarşi kavramları konusunda yaptığı eleştiriler ve açıklamalar eylemin de dönüşmesini sağlamaktadır. Sürdürülebilir kalkınma, insani güvenlik, insani müdahale, eşitlikçi temsil gibi önemli konuların dış politika alanına dahil edilmiş olmasında feminist hareketin etkileri yadsınamaz. Ancak tüm bu düzenleme ve tartışmalara rağmen eril kültürün değiştirilmesi, böylece kurumların cinsiyet eşitliğine duyarlı bir düzeye çekilmesi için daha zamana intiyaç olduğu görülmektedir. 


\section{Kaynakça}

Akdoğan, Itır (2019). Üst Düzey Karar Almada Kadın Katııımı. İstanbul: Tesev Yayınları.

Ataç, Cemile Akça (2017). " 'Başkanlık için Wonder Woman!': 2016 Amerikan Seçimleri, Hillary Clinton ve Feminist Gelecek." Fe Dergi: Feminist Eleştiri 9 (2): 81-94.

Ataman, Muhittin (2009). "Feminizm: Geleneksel Uluslararası Ilişkiler Teorilerine Alternatif Yaklaşımlar Demeti." Alternatif Politika 1 (1): 1-41. Aydın-Koyuncu, Çiğdem (2011). “Dış Politika Karar Verme Mekanizmalarında Kadının Yeri." Amme Idaresi Dergisi 44 (4): 99-120.

Aydın-Koyuncu, Çiğdem (2012). "Feminist Uluslararası 'llişkiler Yaklaşımı Açısından Güvenlik Konusunun Analizi." Ankara Universitesi SBF Dergisi 57 (1): 111-139. Aydın, Mustafa (1996). "Uluslararası İlişkilerde Teori ve Analiz." Ankara Universitesi SBF Dergisi 51 (1):71-114.

Aydın, Mustafa, Fulya Hisarlıoğlu ve Korhan Yazgan (2016). 'Türkiye'de Uluslararası Ilişkiler Akademisyenleri ve Alana Yönelik Yaklaşımları Uzerine Bir Inceleme: TRIP 2014 Sonuçları." Uluslararası Ilişkiler 12 (48): 3-35.

Barker, Alex (2009). "Britain's first female diplomats." Financial Times. https://www.ft.com/content/8e936c88- c9ad-11de-a071-00144feabdc0. Erişim tarihi: 3.5.2019.

Bashevkin, Sylvia (2018). "The Taking of Foggy Bottom? Representation in US Diplomacy." Gendering Diplomacy and International Negotiation. Karin Aggestam ve Ann Towns (der.) içinde. Basingstoke: Palgrave Macmillan. bbc.com (2017). “'̇sveç'in ‘Feminist Hükümeti' İran'da Başörtüsü Takmalarını Savundu." https://www.bbc.com/turkce/haberler-dunya-38960765. Erişim tarihi: 20.07.2019.

Berktay, Fatmagül (2012). "Temsil Politik Bir Meseledir.”

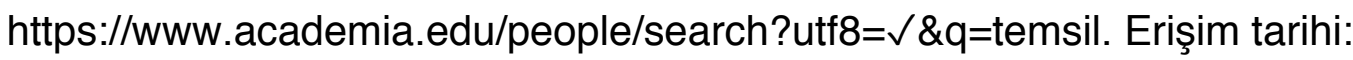
5.5.2019.

Biter, Illkim Tuğçe (2017). "Uluslararası Ilişkilerde Feminist Dış Politika Söylemi ve İsveç Örneği." Alternatif Politika 9(3): 495-524. 
Biyografya.com (Tarihsiz). "Filiz Dinçmen."

https://www.biyografya.com/biyografi/6493. Erişim tarihi: 22.6.2019.

Blanchard, Eric M. (2003). "Gender, International Relations, and the Development of

Feminist Security Theory." Signs: Journal of Women in Culture and Society 28 (4): 1289-1312.

bm1325eylemplani.org, "BMGK 1325." http://bm1325eylemplani.org. Erişim tarihi:

15.07.2019

Caprioli, Mary ve Mark A. Boyer (2001). "Gender, Violence, and International Crisis." Journal of Conflict Resolution 45(4): 503-518.

cocukdayaparimkariyerde.com. (t.y.). "Dışişlerinde Kadınlar Erkek Egemenliğini

Yıktı." http://www.cocukdayaparimkariyerde.com/is-kariyer/is-hayatindakadin/2038- Erişim Tarihi: 22.6.2019

Cohn, Carol ve Cynthia Enloe (2003). "A Conversation with Cynthia Enloe: Feminist Look at Masculinity and the Men Who Wage War." Signs: Journal of Women in Culture and Society 28 (4): 1187-1207.

Connell, Raewyn (1995). Masculinities. Cambridge: Polity Press.

Çevik, Nurten ve Ali Bilgiç (2017). "Ulusötesi Kavramsallaşmasında Kesişimselliğin

Yeri." “Uluslararası" Kavramını Yeniden Düşünmek. Ceren Ergenç ve Derya G. Akder (der.) içinde. 177-202.

Dahlerup, Drude (2001). "Women in Political Decisionmaking: From Critical Mass to Critical Acts in Scandinavia." Gender, Peace and Conflict. Inger-Smith Skjelsbaek (der.) içinde. London: Sage Publications. 104-121.

Demel, Julie Anne (2016). "Female 'Diplomats' from 1815 to Present”, Encyclopédie pour une histoire nouvelle de l'Europe [online] https://ehne.fr/en/article/genderand-europe/gender-citizenship-europe/female-diplomats-europe-1815-present. Erişim tarihi: 11.06.2019

Demirci, Zuhal ve Nazlı Yüzbaşıŏlu (2019). "Hariciyede Kadın Diplomatların Oranı Artıyor." Anadolu Ajansı. https://www.aa.com.tr/tr/turkiye/hariciyede-kadindiplomatlarin-temsil-orani-artiyor/1411557. Erişim tarihi: 16.06.2019.

Doostar, Naimeh (2015). "Dress Code Troubles of Female Diplomats in Iran", Zamaneh Media, 19.06.2015. https://en.radiozamaneh.com/24345/. Erişim tarihi: 22.05.2019. 
Düşünce Mektebi (2018). "Riyad'da Başını Örtmeyi Reddetti İddiası Doğru mu?” https://www.dusuncemektebi.com/d/173678/riyadda-basini-ortmeyi-reddettiiddiasi-Erişim tarihi: 20.05.2019 dw.com (2015). "Germany's von der Leyen Calls for more NATO Defense Spending." https://www.dw.com/en/germanys-von-der-leyen-calls-for-more-nato-defensespending/a-18551385 Erişim tarihi: 14.08.2019 dw.com (2018). "Isveç Hükümetinden Feminist Dış Politika Kılavuzu." 24.08.2018, https://www.dw.com/tr/isveç-hükümetinden-feminist-dış-politikakılavuzu/a45202334. Erişim tarihi: 14.08.2019.

Eagleton, Terry (2011). Kültür Yorumları. Çev., Özge Çelik. İstanbul: Ayrıntı Yayınları.

Eisenstein, Zillah (1999). "Constructing a Theory of Capitalist Patriarchy and Socialist Feminism." Critical Sociology 25(2/3): 196-217.

Eken, Mehmet Evren ve Deniz Erdoğan (2016). "Görsel Diplomasi ve Kadın İmgesi." https://www.academia.edu/18366190/Görsel_Diplomasi_ve_Kadın_İmgesi_201 6_. Erişim tarihi: 7.5.2019.

Eken, Mehmet Evren (2017). "Feminizm, Maskülinite ve Uluslararası İlişkiler Teorisi:

Uluslararası Siyasetin Toplumsal Cinsiyeti." Uluslararası ilişskiler Teorileri.

Ramazan Gözen (der.) içinde. İstanbul: İletişim Yayınları.

Enloe, Cynthia (1990). Bananas, Beaches and Bases: Making Feminist Sense of International Politics. California: University of California Press.

Eralp, Atila (2004). "Uluslararası İlişkiler Disiplinin Oluşumu: İdealizm-Realizm Tartışması." Devlet, Sistem ve Kimlik. Atilla Eralp (der.) içinde. İstanbul: İletişim Yayınları. 57-88.

Feierman, Lisa (2016). "Where Are All the Female Diplomats?" Kennedy School Review. http://harvardkennedyschoolreview.com/where-are-all-the-femalediplomats/. Erişim tarihi: 13.6.2019.

Gazete Karınca (2017). "Devrim Kızılında İlklerin Adı: Aleksandra Kollontay." http://gazetekarinca.com/2017/08/devrim-kizilinda-ilklerin-adi-aleksandrakollontay/. Erişim tarihi: 10.05.2019

Glenda Sluga ve Carolyn James (der.) (2015). Women, Diplomacy and International Politics since 1500. London: Routledge. 
Halliday, Fred, (1991). "Hidden from International Relations: Women and International Arena." Gender and International Relations. Rebecca Grant ve Kathleen Newland (der.) içinde. Bloomington. Open University Press and Indiana University Press. 158-169.

Hooper, Charlotte (2001). Manly States- Masculinities, International Relations, and Gender Politics. New York: Columbia University Press.

İskit, Temel (2015). Diplomasi: Tarihi, Teorisi, Kurumları ve Uygulaması. İstanbul: Bilgi Üniversitesi Yayınları.

Joan, Acker (1990). "Hierarchies, Bodies, and Jobs: A Gendered Theory of Organizations." Gender and Society 4 (2) 139-58.

Kandiyoti, Deniz (2011). “Ataerkil Örüntüler: Türk Toplumunda Erkek Egemenliğinin Çözümlenmesine Yönelik Notlar.” Kadın Bakış Açısından 1980'ler Türkiye'sinde Kadınlar. Şirin Tekeli (der.) içinde. İstanbul: İletişim Yayınları 327-340.

Kirby, Paul (2012). "How is Rape A Weapon of War: Feminist International Relations, Modes of Critical Explanation and the Study of Wartime Sexual Violence." European Journal of International Relations 1-25.

Lamothe Dan (2014). "The US Military's Long, Uncomfortable History with Prestitution Gets New Attention." Washington Post. https://www.washingtonpost.com/news/checkpoint/wp/2014/10/31/the-u-smilitarys-long-uncomfortable-history-with-prostitution-gets-newattention/?noredirect=on\&utm_term=.fb2be6788052. Erişim tarihi: 5.7.2019 Leatherman, Janie (2005). "Gender and U.S. Foreign Policy Hegemonic Masculinity, The War in Iraq, and the UN-Doing of World Order." Gender and American Politics. Sue Tolleson ve Jyl J Josephson Rinehard (der.) içinde. California: M. E. Sharpe. 103-126.

listelist.com (2017). "Doğum Gününde İlk Kadın Türk Diplomat Adile Ayda Hakkında 7 Aydınlatıcı Bilgi.” http://listelist.com/adile-ayda-kimdir/. Erişim tarihi: 22.6.2019.

McCarthy, Helen (2014a). Women of the World: The Rise of the Female Diplomat. London: Bloomsbury.

McCarthy, Helen, (2014b). "The Rise of the Female Diplomat." Prospect http://www.prospectmagazine.co.uk/ opinions/the-rise-of-the-female-diplomat. 
Morgan, Robin (1989). The Demon Lover: On the Sexuality of Terrorism. London: Methuen.

Murphy, Craig N. (1998). "Six Masculine Roles in International Relations." The "Man" Question in International Relations. Marysia Zalewski ve Jane Parpart (der.) içinde. Boulder: Westview. 93-108.

Niklasson, Birgitta ve Felicia Robertson (2018) "The Swedish MFA: Living up to Expectations?" Gendering Diplomacy and International Negotiation. Karin Aggestam ve Ann Towns (der.) içinde. Basingstoke: Palgrave Macmillan. 7879.

Owens, Charlotte (2016). "Sweden Leads Political Thought With A Feminist Foreign Policy." http://theowp.org/reports/sweden-leads-political-thought-with-a-feministforeign-policy/. Erişim tarihi: 14.7.2019.

Özbay, Cenk (2013). “Türkiye'de Hegemonik Erkekliği Aramak.” Doğu Batı 63: 185204.

Pamir, Balçiçek (2006). "Dışişlerinde Kadına Şans Verilmiyor."

http://arsiv.sabah.com.tr/2006/08/28/pamir.html. Erişim tarihi: 22.6.2019.

Pateman, Carole (1988). The Sexual Contract. Stanford: Stanford University Press.

Peterson, V. Spike ve Anne Sisson Runyan (1993). Global Gender Issues. Boulder: Westview Press.

Randall, Vicky (1987). Women and Politics: An International Perspectives. Chicago: University of Chicago Press.

Peirce, Leslie P. (1993). The Imperial Harem: Women and Sovereignty in the Ottoman Empire. New York: Oxford University Press.

Sancar, Serpil (2009). Erkeklik Imkansız Iktidar: Ailede, Piyasada ve Sokakta Erkekler. İstanbul: Metis Yayınları.

Stanley, Matin (t.y.). "Women Diplomats." https://www.civilservant.org.uk/womendiplomats.html. Erişim tarihi: 3.5.2019 star.com (2018). “Türkiye’nin Kadın Askerleri." Star, 27.11.2018. https://www.star.com.tr/guncel/turkiyenin-kadin-askerleri-haber-1411167/. Erişim tarihi: 8.6.2019. 
Süleymanoğlu Kürüm, Rahime ve Bahar Rumelili (2018). "Diplomaside Kadın ve Egemen Maskülenlik: Değişen Normlar ve Pratikler.” Uluslararası Ilişkiler 15 (57): 3-18.

Sylvester, Christine (2002). Feminist International Relations: An Unfinished Journey. Cambridge: Cambridge University Press. 3-17.

Tickner, J. Ann (1991). "Hans Morgenthau's Principles of Political Realism: A feminist Reformulation." Gender and International Relations. Rebecca Grant ve Kathleen Newland (der.) içinde. Indianapolis: Open University Press. 27-32 Tickner, J. Ann (1997). “You Just Don’t Understand: Troubled Engagements Between Feminists and IR Theorists." International Studies Quarterly 41 (4): 611-632. Tickner, J. Ann (1999), "Searching for the Princess? Feminist Perspectives in International Relations." Harvard International Review 21 (4): 44-48.

Toosi, Natal (2014). "Female Diplomats Share Secrets.” Politico, 9 Şubat 2014. http://www.politico.com/story/2014/09/diplomats-women-state-department110506. Erişim tarihi: 23.5.3029.

Towns, Ann ve Birgitta Niklasson (2016). "Gender, International Status and Ambassador Appointments." Foreign Policy Analysis: 1-20.

Tuncer, Hüner (2007). Bir Kadın Diplomatın Anıları. İstanbul: Logos Yayınları. Tür, Özlem ve Çiğdem Aydın Koyuncu (2010). "Feminist Uluslararası İlişkiler Yaklaşımı: Temelleri, Gelişimi, Katkı ve Sorunları." Uluslararası İlişkiler 7 (26): 3-24.

UNECE (2017) "Number of Women Ambassadors Increasing in the UNECE Region." https://www.unece.org/info/media/news/statistics/2017/number-of-womenambassadors-increasing-in-the-unece-region/doc.html. Erişim tarihi: 16.06.2019 Üner, Sarp (2008). "Toplumsal Cinsiyet Eşitliği”, T.C. Başbakanlık Kadın Statüsü Genel Müdürlüğü Kadına Yönelik Aile Içi Şiddetle Mücadele Projesi. https://www.ilkadim.bel.tr/yerel-esitlik/9.pdf. Erişim tarihi: 1.08.2019.

Wilson, Caroline (2017). "Women Leading British Diplomacy Across Europe." Foreign \& Commonwealth Office.

https://blogs.fco.gov.uk/fcoeditorial/2017/03/08/women-leading-britishdiplomacy-across-europe/. Erişim tarihi: 14.5.2019. 
Yelsalı Parmaksız, Pınar Melis (2016). "Kadın Anlatıları Ne Anlatır?” Kadın Hayatlarını Yazmak: Oto/Biyografi, Yaşam Anlatıları, Mitler ve Tarih Yazımı Uluslararası Sempozyum (19-20 Nisan 2019/Istanbul) Bildiri Kitabı. Birsen Talay Keşoğlu ve Leyla Şimşek Rathke (der.) içinde. İstanbul: Kadın Eserleri Kütüphanesi ve Bilgi Merkezi Vakfı Yayınları. 568-572.

Zalewski, Marysia ve Jane Parpart (1995). "Well, What is the Feminist Perspective on Bosnia." International Affairs 72 (2): 339-356.

Zalewski, Marysia ve Jane Parpart (der.) (1998). The "Man" Question in International Relations. Boulder: Westview. 